\title{
Synthesis, magnetic, spectral and biological studies of copper(II) complexes of 4-benzoyl-3-methyl-1-phenyl-2- pyrazolin-5-one N(4)-substituted thiosemicarbazones
}

\author{
Ayman K. El-Sawaf ${ }^{1,2, ~ *, ~ A m a l ~ A b d e l ~ F a t a h ~ N a s s a r ~}{ }^{3}$, El-Sayed El-Samanody ${ }^{1,2}$ \\ ${ }^{1}$ Chemistry Department, College of Science and Humanity Studies, Salman bin Abdulaziz University, AlKharj, KSA.11942 \\ ${ }^{2}$ Chemistry Department, Faculty of Science, Minoufiya University, Shebin El-Kom, Egypt \\ ${ }^{3}$ Chemistry Department, College of Education for Girls, Salman bin Abdulaziz University, KSA
}

\section{Email address:}

elsawaf2008@yahoo.com (A. K. El-Sawaf)

\section{To cite this article:}

Ayman K. El-Sawaf, Amal Abdel Fatah Nassar, El-Sayed El-Samanody. Synthesis, Magnetic, Spectral and Biological Studies of Copper(II) Complexes of 4-Benzoyl-3-Methyl-1-Phenyl-2-Pyrazolin-5-One N(4)-Substituted Thiosemicarbazones. Science Journal of Chemistry. Vol. 2, No. 3, 2014, pp. 17-26. doi: 10.11648/j.sjc.20140203.12

\begin{abstract}
The synthesis and characterization of copper(II) complexes with 4-benzoyl-3-methyl-1-phenyl-2-pyrazolin-5one thiosemicarbazone and $\mathrm{N}(4)$-substituted thiosemicarbazones are reported. Elemental analysis, molar conductivities, magnetic measurements and spectral (i.r., electronic, e.s.r., and n.m.r.) studies have been used to characterize the complexes. The i.r. spectra show that the thiosemicarbazones behave as bidentate ligands, either in the thione or thiolato form. Stereochemistries are proposed for the complexes on the basis of spectral and magnetic studies. Both the thiosemicarbazones and their complexes show either modest or no growth inhibitory activity against Aspergillus niger and Paecilomyces variotii.
\end{abstract}

Keywords: Synthesis, Thiosemicarbazones, Characterization, Complexes, Stereochemistries, Antifungal

\section{Introduction}

Transition metal ion complexes of thiosemicarbazones have been the subject of many articles [1- 4]. These compounds possess a range of biological applications that include antitumor [5], antifungal [6], antiviral [7], antibacterial [8] and antimalarial [9] activities. There have been an increasing number of studies featuring complexes of heterocyclic thiosemicarbazones, particularly thiosemicarbazones prepared from commercially available thiosemicarbazide [10, 11]. In addition, reports concerning iron(III), cobalt(II, III) [12], nickel(II), zinc(II) [13], and copper(II) [14] complexes of 4-formylantipyrine N(4)methyl-, N(4)-dimethyl- and piperidylthiosemicarbazones. We describe here the preparation and characterization of copper(II) complexes with 4-benzoyl-3-methyl-1-phenyl-2pyrazolin-5-one thiosemicarbazone, N(4)-methyl-, N(4)dimethyl- and 3-piperidylthiosemicarbazones (HBATP4DH, HBATP4M, HBATP4DM and HBATPpip, respectively),

\section{Experimental}

\subsection{Materials}

4-benzoyl-3-methyl-1-phenyl-2-pyrazolin-5-one, thiosemicarbazide, N(4)-methyl thiosemicarbazide and copper salts were purchased from Aldrich and used without further purification.

\subsection{Synthesis of Ligands}

N(4)-Dimethyl thiosemicarbazide and 3piperidylthiosemicarbazide were prepared following the method of Scovill [15]. Thiosemicarbazones were prepared by mixing equimolar amounts of 4-benzoyl-3-methyl-1phenyl-2-pyrazolin-5-one and the desired thiosemicarbazide in anhydrous EtOH and stirring for $2 \mathrm{hrs}$.

\subsection{Synthesis of Metal Complexes}

All the metal complexes were prepared by adding a solution of the copper(II) salt $(0.002 \mathrm{~mol})$ in $\mathrm{EtOH}\left(40 \mathrm{~cm}^{3}\right)$ was mixed with a solution of the desired thiosemicarbazone 
$(0.002 \mathrm{~mol})$ in $\mathrm{EtOH}\left(40 \mathrm{~cm}^{3}\right)$, and the resulting mixture was stirred under reflux for $3 \mathrm{hrs}$. The resulting solids were filtered off and placed on a warm plate at $35{ }^{\circ} \mathrm{C}$ until required for characterization.

\subsection{Instruments}

IR spectra of the solid ligands and there complexes were recorded on Perkin-Elmer infrared spectrometer 681 or Perkin-Elmer 1430 using $\mathrm{KBr}$ disc. The ${ }^{1} \mathrm{H}$ NMR spectra were recorded with a JEOL EX-270 MHz or JEOL ECA-500 MHz FT-NMR spectrometer in $\mathrm{d}_{6}$-DMSO as solvent, where the chemical shifts were determined relative to the solvent peaks. The molar conductivity of the metal complexes in DMF at $10^{-3} \mathrm{M}$ concentration was measured using a dip cell and a Bibby conductimeter MC1 at room temperature. The resistance measured in ohms whereas the molar conductivities were calculated according to the equation: $\Lambda=\mathrm{V} \times \mathrm{K} \times \mathrm{Mw} / \mathrm{g} \times \Omega$, where: $\Lambda=$ molar conductivity (ohm $\left.{ }^{1} \mathrm{~cm}^{2} \mathrm{~mol}^{-1}\right), \mathrm{V}=$ volume of the complex solution, $\mathrm{K}=$ cell constant $0.92 \mathrm{~cm}^{-1}, \mathrm{Mw}=$ molecular weight of the complex, $\mathrm{g}=$ weight of the complex, $\Omega=$ resistance measured in ohms. Electronic absorption spectra (Near infrared / Visible / Ultraviolet) were recorded on a Perkin Elmer 550 spectrometer using $\mathrm{cm}^{-1}$ quartz cells taking DMSO as solvent. The nujol mull electronic absorption spectra were recorded using whatman filter paper No.1 and referenced against another similar filter paper saturated with paraffin oil. The magnetic susceptibilities of the polycrystalline complexes were measured in a borosilicate tube with a Johnson Matthey Magnetic susceptibility Balance at room temperature using the modified Gouy method. The solid ESR spectra of the complexes recorded with ELEXSYS E500 Bruker spectrometer in 3-mm Pyrex Tubes at $298{ }^{\circ} \mathrm{K}$. Diphenylpicrylhydrazide (DPPH) was used as a g-marker for the calibration of the spectra. The elemental analysis (CHN) was performed in the Microanalytical Unit within Cairo University (Egypt) by the usual methods of analysis. All the thiosemicarbazones and their copper(II) chloride and copper(II) bromide complexes were examined for biological activity by testing them against two pathogenic human fungi, Aspergillus niger and Paecilomyces variiotti. Testing was done using an agar diffusion method. Sabourad Dextrose Agar $(25 \mathrm{ml})$ was poured into petri dishes and after solidification, a $0.5 \mathrm{ml}$ portion of a spore suspension containing the desired fungi was added. The $6 \mathrm{~mm}$ assay disks were saturated with a dimethylsulfoxide solution containing either a thiosemicarbazone or a metal ion complex. Five concentrations were tested: 200, 400, 600, 1000 and $1600 \mu \mathrm{g} / \mathrm{ml}$. The antifungal activity was determined by measuring the diameter of the inhibition zones An average value for each solution was obtained by discarding the high and low values and averaging the remaining six. These values were compared to nystatin, a commercially available antifungal agent.

\section{Results and Discussion}

The prepared ligands were investigated by elemental analyses (Table 1) and $\left({ }^{1}\right.$ HNMR and infrared) spectroscopy (Table 2).

Table 1. Colors, partial elemental analyses, molar conductivities and magnetic susceptibilities of the copper(II) complexes of 4-Benzoyl-3-methyl-1phenyl-2-pyrazolin-5-one N(4)-Substituted Thiosemicarbazones

\begin{tabular}{|c|c|c|c|c|c|c|c|c|}
\hline \multirow{2}{*}{ No. } & \multirow{2}{*}{ Compound } & \multirow{2}{*}{ Color, Fw. } & \multicolumn{4}{|c|}{ Found (Calc)\% } & \multirow{2}{*}{$\Lambda-{ }^{\mathrm{a}}{ }_{\mathrm{M}}$} & \multirow{2}{*}{$\begin{array}{l}{ }^{\mu} \text { eff } \\
\text { (B.M. })^{a}\end{array}$} \\
\hline & & & $\mathrm{C}$ & $\mathbf{H}$ & $\mathbf{N}$ & Cl & & \\
\hline \multirow{4}{*}{1} & HBATP4DH & White & 61.87 & 5.02 & 19.88 & 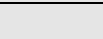 & \multirow{2}{*}{-} & \\
\hline & $\mathrm{C}_{18} \mathrm{H}_{17} \mathrm{~N}_{5} \mathrm{OS}$ & 337.49 & $(61.52)$ & $(4.88)$ & $(19.93)$ & - & & \\
\hline & {$\left[\mathrm{Cu}(\mathrm{HBATP} 4 \mathrm{DH}) \mathrm{Cl}_{2}\right] \cdot 2 \mathrm{H}_{2} \mathrm{O}$} & Green & 40.96 & 4.24 & 13.92 & 13.97 & & \\
\hline & $\mathrm{C}_{18} \mathrm{H}_{21} \mathrm{Cl}_{2} \mathrm{CuN}_{5} \mathrm{O}_{3} \mathrm{~S}$ & 521.91 & $(41.42)$ & $(4.06)$ & $(13.42)$ & 13.59 & 24.5 & 1.83 \\
\hline \multirow{2}{*}{2} & {$\left[\mathrm{Cu}(\mathrm{HBATP} 4 \mathrm{DH}) \mathrm{Br}_{2}\right] \cdot \mathrm{H}_{2} \mathrm{O}$} & Green & 36.96 & 3.34 & 11.92 & & \multirow{2}{*}{18.7} & \multirow{2}{*}{1.78} \\
\hline & $\mathrm{C}_{18} \mathrm{H}_{19} \mathrm{Br}_{2} \mathrm{CuN}_{5} \mathrm{O}_{2} \mathrm{~S}$ & 592.80 & $(36.47)$ & $(3.23)$ & $(11.81)$ & & & \\
\hline \multirow{2}{*}{3} & {$[\mathrm{Cu}(\mathrm{BATP} 4 \mathrm{DH})(\mathrm{OAc})]_{2} \cdot \mathrm{H}_{2} \mathrm{O}$} & Green & 51.90 & 5.04 & 13.82 & & \multirow{2}{*}{11.9} & \multirow{2}{*}{0.93} \\
\hline & $\mathrm{C}_{44} \mathrm{H}_{51} \mathrm{Cu}_{2} \mathrm{~N}_{10} \mathrm{O}_{7} \mathrm{~S}_{2}$ & 1023.16 & $(51.65)$ & $(5.02)$ & (13.69) & & & \\
\hline \multirow{4}{*}{4} & {$\left[\mathrm{Cu}(\mathrm{HBATP} 4 \mathrm{DH})_{2}\right] \cdot\left(\mathrm{BF}_{4}\right)_{2}$} & Green & 47.40 & 3.40 & 14.87 & & \multirow{2}{*}{133.5} & \multirow{2}{*}{1.74} \\
\hline & $\mathrm{C}_{36} \mathrm{H}_{34} \mathrm{~B}_{2} \mathrm{Cu} \mathrm{F}_{8} \mathrm{~N}_{10} \mathrm{O}_{2} \mathrm{~S}_{2}$ & 940.00 & $(46.00)$ & $(3.65)$ & $(14.90)$ & & & \\
\hline & HBATP4M & Pale yellow & 61.50 & 5.21 & 19.22 & 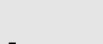 & 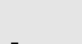 & \\
\hline & $\mathrm{C}_{19} \mathrm{H}_{19} \mathrm{~N}_{5} \mathrm{OS}$ & 365.45 & $(62.45)$ & $(5.24)$ & (19.16) & & - & \multirow{3}{*}{1.92} \\
\hline \multirow{2}{*}{5} & {$\left[\mathrm{Cu}(\mathrm{HBATP} 4 \mathrm{M}) \mathrm{Cl}_{2}\right] \cdot \mathrm{H}_{2} \mathrm{O}$} & Blue & 44.10 & 4.44 & 13.70 & 13.89 & \multirow{2}{*}{28.5} & \\
\hline & $\mathrm{C}_{19} \mathrm{H}_{21} \mathrm{Cl}_{2} \mathrm{CuN}_{5} \mathrm{O}_{2} \mathrm{~S}$ & 517.92 & $(44.06)$ & $(4.09)$ & $(13.52)$ & 13.69 & & \\
\hline \multirow{2}{*}{6} & [Cu(HBATP4M)Br $\left.{ }_{2}\right]$ & Blue & 38.70 & 3.20 & 11.70 & & \multirow{2}{*}{30.2} & \multirow{2}{*}{1.71} \\
\hline & $\mathrm{C}_{19} \mathrm{H}_{19} \mathrm{Br}_{2} \mathrm{CuN}_{5} \mathrm{O} \mathrm{S}$ & 588.81 & $(38.76)$ & $(3.25)$ & (11.89) & & & \\
\hline \multirow{2}{*}{7} & {$[\mathrm{Cu}(\mathrm{BATP} 4 \mathrm{M})(\mathrm{OAc})]_{2}$} & Brown & 53.19 & 5.80 & 13.24 & 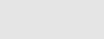 & \multirow{2}{*}{10.7} & \multirow{2}{*}{0.96} \\
\hline & $\mathrm{C}_{46} \mathrm{H}_{53} \mathrm{Cu}_{2} \mathrm{~N}_{10} \mathrm{O}_{6} \mathrm{~S}_{2}$ & 1033.20 & $(53.48)$ & $(5.17)$ & $(13.56)$ & - & & \\
\hline \multirow{4}{*}{8} & $\left.\left[\mathrm{Cu}(\mathrm{HBATP} 4 \mathrm{M})_{2}\right] \cdot\left(\mathrm{BF}_{4}\right)_{2}\right] \cdot \mathrm{H}_{2} \mathrm{O}$ & Buff & 43.40 & 4.93 & 9.60 & & \multirow{4}{*}{126.3} & \multirow{4}{*}{1.58} \\
\hline & $\mathrm{C}_{38} \mathrm{H}_{40} \mathrm{~B}_{2} \mathrm{Cu} \mathrm{F} \mathrm{F}_{10} \mathrm{O}_{3} \mathrm{~S}_{2}$ & 986.07 & $(46.29)$ & $(4.09)$ & $(9.36)$ & - & & \\
\hline & HBATP4DM & yellow & 63.40 & 5.93 & 18.60 & & & \\
\hline & $\mathrm{C}_{20} \mathrm{H}_{21} \mathrm{~N}_{5} \mathrm{OS}$ & 379.48 & $(63.30)$ & $(5.58)$ & $(18.46)$ & & & \\
\hline \multirow{2}{*}{9} & [Cu(HBATP4DM) $\left.\mathrm{Cl}_{2}\right] \cdot \mathrm{H}_{2} \mathrm{O}$ & Brown & 45.61 & 4.20 & 13.80 & 13.90 & & \\
\hline & $\mathrm{C}_{20} \mathrm{H}_{23} \mathrm{Cl}_{2} \mathrm{CuN}_{5} \mathrm{O}_{2} \mathrm{~S}$ & 531.95 & $(45.16)$ & $(4.36)$ & $(13.17)$ & $(13.33)$ & 19.50 & 1.74 \\
\hline 10 & {$\left[\mathrm{Cu}(\mathrm{HBATP} 4 \mathrm{DM}) \mathrm{Br}_{2}\right] \cdot 2 \mathrm{H}_{2} \mathrm{O}$} & Brown & 37.61 & 4.20 & 10.80 & & & \\
\hline 10 & $\mathrm{C}_{20} \mathrm{H}_{25} \mathrm{Br}_{2} \mathrm{CuN}_{5} \mathrm{O}_{3} \mathrm{~S}$ & 638.86 & $(37.60)$ & $(3.94)$ & $(10.96)$ & & 17.7 & 1.63 \\
\hline 11 & {$[\mathrm{Cu}(\mathrm{BATP} 4 \mathrm{DM})(\mathrm{OAc})]_{2} \cdot \mathrm{H}_{2} \mathrm{O}$} & Brown & 53.61 & 5.21 & 13.80 & & 11.3 & 0.86 \\
\hline
\end{tabular}




\begin{tabular}{|c|c|c|c|c|c|c|c|c|}
\hline \multirow{2}{*}{ No. } & \multirow{2}{*}{ Compound } & \multirow{2}{*}{ Color, Fw. } & \multicolumn{4}{|c|}{ Found (Calc)\% } & \multirow{3}{*}{$\Lambda-{ }^{\mathrm{a}}{ }_{\mathrm{M}}$} & \multirow{2}{*}{$\begin{array}{l}\text { "eff } \\
(\text { (B.M. })^{\mathrm{a}}\end{array}$} \\
\hline & & & $\mathbf{C}$ & $\mathbf{H}$ & $\mathbf{N}$ & Cl & & \\
\hline \multirow{5}{*}{12} & $\mathrm{C}_{47} \mathrm{H}_{56} \mathrm{Cu}_{2} \mathrm{~N}_{10} \mathrm{O}_{7} \mathrm{~S}_{2}$ & 1064.24 & $(53.04)$ & $(5.30)$ & $(13.16)$ & \multirow{13}{*}{$\begin{array}{l}12.92 \\
(12.80)\end{array}$} & & \multirow{5}{*}{1.57} \\
\hline & {$\left[\mathrm{Cu}(\mathrm{HBATP} 4 \mathrm{DM})_{2}\right] \cdot\left(\mathrm{BF}_{4}\right)_{2}$} & Brown & 47.61 & 4.21 & 14.80 & & \multirow{4}{*}{119.7} & \\
\hline & $\mathrm{C}_{39} \mathrm{H}_{39} \mathrm{~B}_{2} \mathrm{Cu} \mathrm{F} \mathrm{F}_{8} \mathrm{~N}_{10} \mathrm{O}_{3} \mathrm{~S}_{2}$ & 981.08 & $(47.75)$ & $(4.01)$ & $(14.28)$ & & & \\
\hline & HBATPрір & Yellow & 65.61 & 6.21 & 16.84 & & & \\
\hline & $\mathrm{C}_{23} \mathrm{H}_{25} \mathrm{~N}_{5} \mathrm{OS}$ & 419.54 & $(65.85)$ & $(6.01)$ & (16.69) & & & \\
\hline \multirow{2}{*}{13} & [Cu(HBATPpip) $\left.\mathrm{Cl}_{2}\right]$ & Brown & 49.61 & 4.20 & 12.75 & & \multirow{2}{*}{16.3} & \multirow{2}{*}{1.84} \\
\hline & $\mathrm{C}_{20} \mathrm{H}_{23} \mathrm{Cl}_{2} \mathrm{CuN}_{5} \mathrm{O}_{2} \mathrm{~S}$ & 554.00 & $(49.87)$ & $(4.55)$ & (12.64) & & & \\
\hline \multirow[t]{2}{*}{14} & [Cu(HBATPpip) $\left.\mathrm{Br}_{2}\right] \cdot \mathrm{H}_{2} \mathrm{O}$ & Brown & 41.74 & 4.30 & 10.79 & & \multirow[t]{2}{*}{10.6} & \multirow[t]{2}{*}{1.74} \\
\hline & $\mathrm{C}_{23} \mathrm{H}_{27} \mathrm{Br}_{2} \mathrm{CuN}_{5} \mathrm{O}_{2} \mathrm{~S}$ & 660.91 & $(41.80)$ & $(4.12)$ & $(10.60)$ & & & \\
\hline \multirow{2}{*}{15} & {$\left[\mathrm{Cu}\right.$ (BATPpip) (OAc)]. $\mathrm{H}_{2} \mathrm{O}$} & Brown & 53.77 & 5.36 & 12.64 & & \multirow{2}{*}{18.3} & \multirow{2}{*}{1.81} \\
\hline & $\mathrm{C}_{25} \mathrm{H}_{30} \mathrm{Cu} \mathrm{N}_{5} \mathrm{O}_{4} \mathrm{~S}$ & 560.15 & $(53.61)$ & $(5.40)$ & (12.50) & & & \\
\hline \multirow{2}{*}{16} & $\left.[\mathrm{Cu} \text { (HBATPpip) })_{2}\right] \cdot\left(\mathrm{BF}_{4}\right)_{2} \mathrm{H}_{2} \mathrm{O}$ & Brown & 50.26 & 4.65 & 12.76 & & \multirow{2}{*}{22.5} & \multirow{2}{*}{1.88} \\
\hline & $\mathrm{C}_{46} \mathrm{H}_{52} \mathrm{~B}_{2} \mathrm{Cu} \mathrm{F}_{8} \mathrm{~N}_{10} \mathrm{O}_{3} \mathrm{~S}_{2}$ & 1094.26 & $(50.49)$ & $(4.79)$ & $(12.80)$ & & & \\
\hline
\end{tabular}

$\mathrm{a}=\Omega^{-1} \mathrm{~mol}^{-1} \mathrm{~cm}^{2}$

Table 2. Infrared spectra ( $\left.\mathrm{cm}^{-1}\right)$ of 4-Benzoyl-3-methyl-1-phenyl-2-pyrazolin-5-one N(4)-Substituted Thiosemicarbazones and their Copper(II) complexes.

\begin{tabular}{|c|c|c|c|c|c|c|c|}
\hline No. & Compound & $v[\mathbf{N}(4) \mathbf{H})]$ & $v(\mathbf{C}=\mathbf{N})$ & $v(\mathbf{C}=\mathbf{S})$ & $v(\mathbf{M}-\mathbf{N})$ & $v(\mathbf{M}-\mathbf{S})$ & $\mathrm{v}(\mathrm{M}-\mathrm{Cl})$ \\
\hline & HBATP4DH & $\begin{array}{l}3425(\mathrm{~s}) \\
3244(\mathrm{~s})\end{array}$ & 1595(m) & $840(s)$ & -- & -- & -- \\
\hline 1 & {$\left[\mathrm{Cu}(\mathrm{HBATP} 4 \mathrm{DH}) \mathrm{Cl}_{2}\right] \cdot 2 \mathrm{H}_{2} \mathrm{O}$} & $\begin{array}{l}3370(\mathrm{~s}) \\
3295(\mathrm{w})\end{array}$ & $1587(\mathrm{~s})$ & $840(\mathrm{~s})$ & 452(m) & $368(\mathrm{~m})$ & $\begin{array}{l}325(\mathrm{~s}) \\
312(\mathrm{~m})\end{array}$ \\
\hline 2 & [Cu(HBATP4DH)Br $\left.{ }_{2}\right] . \mathrm{H}_{2} \mathrm{O}$ & $\begin{array}{l}3367(\mathrm{~m}) \\
3288(\mathrm{w})\end{array}$ & 1582(m) & $732(\mathrm{~s})$ & 448(w) & $346(w)$ & -- \\
\hline 3 & {$[\mathrm{Cu}(\mathrm{BATP} 4 \mathrm{DH})(\mathrm{OAc})]_{2} \cdot \mathrm{H}_{2} \mathrm{O}$} & $\begin{array}{l}3425(\mathrm{~m}) \\
3327(\mathrm{~m})\end{array}$ & $\begin{array}{l}1580(\mathrm{~s}) \\
1572(\mathrm{~m})\end{array}$ & $720(s)$ & 454(m) & 344(w) & -- \\
\hline 4 & $\left.\left[\mathrm{Cu}(\mathrm{HBATP} 4 \mathrm{DH})_{2}\right] \cdot\left(\mathrm{BF}_{4}\right)_{2}\right]$ & $\begin{array}{l}3445(\mathrm{~s}) \\
3226(\mathrm{~m})\end{array}$ & $1677(\mathrm{~m})$ & $738(\mathrm{~s})$ & 452(w) & $344(w)$ & -- \\
\hline & НВАТР4M & $3385(\mathrm{~s})$ & $1605(\mathrm{~s})$ & $852(\mathrm{~m})$ & -- & -- & -- \\
\hline 5 & {$\left[\mathrm{Cu}(\mathrm{HBATP} 4 \mathrm{M}) \mathrm{Cl}_{2}\right] \cdot \mathrm{H}_{2} \mathrm{O}$} & $3342(\mathrm{~m})$ & $1587(\mathrm{~s})$ & $775(\mathrm{~s})$ & $455(\mathrm{~m})$ & $338(w)$ & $\begin{array}{l}318(\mathrm{~s}) \\
308(\mathrm{~m})\end{array}$ \\
\hline 6 & [Cu(HBATP4M)Br $\left.{ }_{2}\right]$ & $3295(\mathrm{~s})$ & 1584(s) & $785(\mathrm{~s})$ & 457(m) & $320(\mathrm{~m})$ & -- \\
\hline 7 & {$[\mathrm{Cu}(\mathrm{BATP} 4 \mathrm{M})(\mathrm{OAc})]_{2}$} & 3264(m) & 1588(s) & 774(s) & 458(w) & $330(w)$ & -- \\
\hline 8 & $\begin{array}{l}\left.\left[\mathrm{Cu}(\mathrm{HBATP} 4 \mathrm{M})_{2}\right] \cdot\left(\mathrm{BF}_{4}\right)_{2}\right] \cdot \mathrm{H}_{2} \mathrm{O} \\
\text { HBATP4DM }\end{array}$ & $\begin{array}{l}3324(\mathrm{~m}) \\
--\end{array}$ & $\begin{array}{l}1580(\mathrm{~s}) \\
1600(\mathrm{~s})\end{array}$ & $\begin{array}{l}784(\mathrm{~m}) \\
830(\mathrm{~m})\end{array}$ & $\begin{array}{l}462(m) \\
--\end{array}$ & $\begin{array}{l}320(\mathrm{~s}) \\
--\end{array}$ & -- \\
\hline 9 & {$\left[\mathrm{Cu}(\mathrm{HBATP} 4 \mathrm{DM}) \mathrm{Cl}_{2}\right] \cdot \mathrm{H}_{2} \mathrm{O}$} & -- & $1576(\mathrm{~m})$ & $795(\mathrm{~s})$ & $456(\mathrm{~m})$ & $332(\mathrm{~m})$ & $\begin{array}{l}318(\mathrm{~s}) \\
302(\mathrm{~m})\end{array}$ \\
\hline 10 & {$\left[\mathrm{Cu}(\mathrm{HBATP} 4 \mathrm{DM}) \mathrm{Br}_{2}\right] \cdot 2 \mathrm{H}_{2} \mathrm{O}$} & -- & 1573(m) & $780(s)$ & $450(\mathrm{~m})$ & $338(w)$ & -- \\
\hline 11 & {$[\mathrm{Cu}(\mathrm{BATP} 4 \mathrm{DM})(\mathrm{OAc})]_{2} \cdot \mathrm{H}_{2} \mathrm{O}$} & -- & $1568(\mathrm{~m})$ & $776(\mathrm{~s})$ & 447(m) & 344(m) & -- \\
\hline 12 & $\begin{array}{l}{\left[\mathrm{Cu}(\mathrm{HBATP} 4 \mathrm{DM})_{2}\right] \cdot\left(\mathrm{BF}_{4}\right)_{2}} \\
\text { HBATPpip }\end{array}$ & $\begin{array}{l}-- \\
--\end{array}$ & $\begin{array}{l}1570(\mathrm{~m}) \\
1592(\mathrm{~s})\end{array}$ & $\begin{array}{l}792(\mathrm{~m}) \\
840(\mathrm{~s})\end{array}$ & $\begin{array}{l}450(w) \\
--\end{array}$ & $\begin{array}{l}344(w) \\
--\end{array}$ & -- \\
\hline 13 & {$\left[\mathrm{Cu}\right.$ (HBATPpip) $\left.\mathrm{Cl}_{2}\right]$} & -- & $1576(\mathrm{~m})$ & $775(\mathrm{~m})$ & 448(m) & $342(w)$ & $\begin{array}{l}320(\mathrm{~m}) \\
302(\mathrm{w})\end{array}$ \\
\hline 14 & {$\left[\mathrm{Cu}\right.$ (HBATPpip) $\left.\mathrm{Br}_{2}\right] \cdot \mathrm{H}_{2} \mathrm{O}$} & -- & $1573(\mathrm{~s})$ & $748(m)$ & $456(w)$ & $346(w)$ & -- \\
\hline 15 & {$\left[\mathrm{Cu}\right.$ (BATPpip) (OAc)]. $\mathrm{H}_{2} \mathrm{O}$} & -- & $\begin{array}{l}1580(\mathrm{~s}) \\
1564(\mathrm{~m})\end{array}$ & $740(s)$ & $450(\mathrm{~m})$ & 342(w) & -- \\
\hline 16 & $\left.[\mathrm{Cu} \text { (HBATPpip })_{2}\right] \cdot\left(\mathrm{BF}_{4}\right)_{2} \mathrm{H}_{2} \mathrm{O}$ & -- & $1570(\mathrm{~s})$ & 784(m) & 448(w) & $344(w)$ & -- \\
\hline
\end{tabular}

The ${ }^{1}$ H-n.m.r. spectra confirm the purity of the thiosemicarbazones. Both BATP4DM and HBATPpip exist as the Z-isomer with intramolecular hydrogen bonding in $\mathrm{CDCl}_{3}$, based on the appearance of $\mathrm{N}(2) \mathrm{H}$ resonance at $\delta$ (P.P.m) ca. 13.3. In $\left.{ }^{2} \mathrm{H}_{6}\right] \mathrm{DMSO}$ there is a mixture of the $\mathrm{Z}$ isomer, the $\mathrm{E}$ isomer with hydrogen bonding to the solvent ( $\delta c a$. 10.7) and a bifurcated tautomer ( i.e. hydrogen bonding to carbonyl oxygen and thiolato sulfur) in which the $\mathrm{N}(2) \mathrm{H}$ is transferred to $\mathrm{N}(1)$, resulting in a conjugated thiosemicarbazone moiety and yellow colour. Therefore, the resonance at $\delta=11.2$ in the spectrum of HBATP4M is assigned to $\mathrm{N}(2) \mathrm{H}$, which is hydrogen bonded to the $\left[{ }^{2} \mathrm{H}_{6}\right]$ DMSO solvent; it and the resonance at $\delta=7.8$ disappear in the presence of $\mathrm{D}_{2} \mathrm{O}$, confirming the assignment of the latter as $\mathrm{N}(4) \mathrm{H}$. This resonance for
$\mathrm{N}(2) \mathrm{H}$ is considerably upfield from that found for HBATP4DH $\delta=7.9$ [16].

The stoichiometries of the copper(II) complexes of 4Benzoyl-3-methyl-1-phenyl-2-pyrazolin-5-one N(4)substituted thiosemicarbazones (HBATP4M, HBATP4DM and HBATPpip) are shown in Table 2. Complexes of the neutral ligands are generally formed unless OAc is included in the preparative mixture. However due to the bulkiness of both HBATP4DM and HBATPpip, two complexes, [Cu(HBATP4DM) (BATP4DM) $] \mathrm{BF}_{4}$ and [Cu(HBATPpip) (BATPpip) $] \mathrm{BF}_{4}$, are isolated with both neutral and anionic ligands. The neutral and anionic form of the ligand appears to coordinate in bidentate NS fashion and the carbonyl oxygen of the pyrazolone ring is not involved in coordination. Only the complexes prepared from copper(II) 
tetrafluoroborate are electrolytes and the elevated molar conductivities found for some of the chloro complexes are probably due to partial decomposition in solution. The magnetic moments approach the theoretical value of 1.73 B.M. for mononuclear copper(II) complexes, except for the three binuclear copper(II) complexes derived from the acetate salts. These complexes have values in the 0.6-1.2 B.M. range, indicating significant interaction between copper(II) centres.

\subsection{Infrared Spectra}

The infrared spectral bands most useful for determining the thiosemicarbazon's mode of coordination are given in (Table 2).

Decreases in the $v(\mathrm{C}=\mathrm{N})$ energy by $15-40 \mathrm{~cm}^{-1}$ on complexation are consistent with coordination of the azomethine nitrogen, as is the presence of a band at $c a .450$ $\mathrm{cm}^{-1}$, which is assigned to $\mathrm{v}(\mathrm{M}-\mathrm{N})$ for this nitrogen [17]. A second band assignable to $v(\mathrm{C}=\mathrm{N})$ is expected in the spectra of those complexes having anionic thiosemicarbazone ligands, since the anionic ligand formally has a double bond between $\mathrm{N}(2)$ and $\mathrm{C}(3)$ of the thiosemicarbazone moiety [18]. The increase for the $v(\mathrm{~N}-\mathrm{N})$ frequency in the spectra of the complexes is probably due to enhanced double bond character through chelation, thus offsetting the loss of electron density via donation to metal ion, and is supportive of azomethine nitrogen coordination. Coordination of the thione/thiolato sulfur is indicated by a decrease in energy of the thioamide IV band, which derives considerable intensity from $v(\mathrm{CS})$, as well as a band in the the $330-360 \mathrm{~cm}^{-1}$ range, assignable to $\mathrm{v}(\mathrm{Cu} \mathrm{S})$ [19]. As expected, greater energy decreases in the thioamide IV band occur for the anionic form of the ligand due to C-S formally becoming a single bond [20]. A band in the 1640$1660 \mathrm{~cm}^{-1}$ region of the spectrum of the thiosemicarbazones is found essentially unchanged in the spectra of the complexes, which indicates that the carbonyl oxygen is not involved in coordination [21]. The spectra of the chloro complexes show two assignable, strong to medium intensity $v(\mathrm{Cu}-\mathrm{Cl})$ bands in the $300-330 \mathrm{~cm}^{-1}$, range indicative of terminal chloro ligands [22]. We are unable to assign $v(\mathrm{Cu}-\mathrm{Br})$ bands with our spectrometer.

Extensive infrared spectral studies reported on metal acetate complexes [23] indicate that the acetate ligand may coordinate to a metal centre in a monodentate, bidentate or bridging manner. The $\mathrm{v}_{\mathrm{a}}\left(\mathrm{CO}_{2}\right)$ and $\mathrm{v}_{\mathrm{s}}\left(\mathrm{CO}_{2}\right)$ of the free acetate ions are at 1560 and $1416 \mathrm{~cm}^{-1}$, respectively. For monodentate coordination the resulting $v(\mathrm{C}=\mathrm{O})$ is found at a higher energy than $v_{a}\left(\mathrm{CO}_{2}\right)$ and $v(\mathrm{C}-\mathrm{O})$ is at lower energy than $v_{s}\left(\mathrm{CO}_{2}\right)$. As a result, the separation between the two $v$ (CO) bands is much larger in monodentate complexes than for the free ion, but with bidentate acetate coordination (i.e. non-bridging Or bridging) the separation between $v(\mathrm{CO})$ bands is smaller than for the free ion. The two $v(\mathrm{CO})$ bands in the spectra of the acetate complexes under study have $\mathrm{v}_{\mathrm{a}}\left(\mathrm{CO}_{2}\right)$ at $c a .1590 \mathrm{~cm}^{-1}$ with $\mathrm{v}_{\mathrm{s}}\left(\mathrm{CO}_{2}\right)$ at $c a .1470 \mathrm{~cm}^{-1}$, suggestive of bridging bidentate coordination, which results in the lower magnetic moment [24].

The absence of coordinated water molecules from the complexes under study is confirmed by the absence of the rocking, twisting and wagging vibrational modes which are normally activated at $970-930 \mathrm{~cm}^{-1}$ and $660-600 \mathrm{~cm}^{-1}$ and in the same time the presence of weak and broad band at ca. $3520 \mathrm{~cm}^{-1}$ indicating that the water in all of these complexes is lattice [25]. A broad band at ca. $1060 \mathrm{~cm}^{-1}$, assignable to $v_{3}\left(\mathrm{BF}_{4}\right)$, and a relatively sharp band at ca. 510 $\mathrm{cm}^{-1}$ due to $\mathrm{v}_{4}\left(\mathrm{BF}_{4}\right)$ indicate non-coordination [26] of the tetrafluoroborate ions in all compounds, in agreement with the molar conductivity results (Table 1).

\subsection{Magnetic Susceptibilities}

The magnetic moment values for the mononuclear copper(II) complexes are close to spin-only value for one unpaired spin ( 1.7 B.M.) at room temperature. As magnetic susceptibilities of the complexes were not determined below room temperature, nothing can be said about the presence or absence of magnetic exchange. Dark green acetate complexes display a subnormal magnetic moment values ( 1.2 B.M.) at room temperature which suggests that the compounds have dimeric structures in which magnetic exchange takes place probably by means of overlap of the $d_{x}{ }^{2}-y^{2}$ orbitals and the spin exchange interactions between copper(II) ions may be explained on the basis of bridging by acetate ligand. A sulfur-bridged dimeric structure seems unlikely since sulfur-bridging leads to very strong antimagnetic interaction resulting in complete diamagnetism in copper(II) complexes.

\subsection{Electronic Absorption Spectra}

Listed in (Table 3) are the energies of the solid state electronic transition for the three thiosemicarbazones, as well as their copper(II) complexes. Omitted from Table 3 are the higher energy $\pi \rightarrow \pi^{*}$ transitions $\left(c a .34500 \mathrm{~cm}^{-1}\right)$ which are not significantly altered on complex formation. The $n \rightarrow \pi^{*}$ transition associated with the azomethine portion of the thiosemicarbazone portion of the thiosemicarbazone moiety is in the region $28000-31000 \mathrm{~cm}^{-1}$ in the spectra of the thiosemicarbazones and altered significantly on complexation (Table 3 ). A second $n \rightarrow \pi^{*}$ transition originating from the thioamide portion of the thiosemicarbazone moiety is found at somewhat lower energies $\left(27000-30000 \mathrm{~cm}^{-1}\right)$. In the copper(II) complexes this latter band generally shifts to higher energies and sometimes merges with the $n \rightarrow \pi^{*}$ transition associated with the azomethine portion [27]. Also present at energies below $30000 \mathrm{~cm}^{-1}$ in the spectra of the copper(II) complexes are $\mathrm{S} \rightarrow \mathrm{Cu}^{\text {II }}$ charge transfer bands, as well as $\mathrm{Br} \rightarrow \mathrm{Cu}^{\text {II }}$ charge transfer bands [28]. The $\mathrm{Cl} \rightarrow \mathrm{Cu}^{\text {II }}$ bands are generally found in the $29000 \mathrm{~cm}^{-1}$ region of the spectrum [29]. This series of complexes has very broad bands due to the $n \rightarrow \pi^{*}$ transitions, and it is difficult to assign energies to the transition between 20000 and $30000 \mathrm{~cm}^{-1}$. The four coordinate copper(II) complexes have a lower energy shoulder, $d_{x} 2-y 2 \rightarrow d_{x z}$, on the main $d \rightarrow d$ composite 
band consistent with an essentially square planar arrangement [30]. The $\mathrm{d} \rightarrow \mathrm{d}$ maximum of the main band,

which is assigned to transitions to $\mathrm{d}_{\mathrm{x}} 2-\mathrm{y} 2$ from , $\mathrm{d}_{\mathrm{xz}}, \mathrm{d}_{\mathrm{yz}}$, and, $\mathrm{d}_{\mathrm{z}} 2$, is found at $c a .17000 \mathrm{~cm}^{-1}$.

Table 3. Solid state electronic spectra ( $\left.\mathrm{cm}^{-1}\right)$ of 4-Benzoyl-3-methyl-1-phenyl-2-pyrazolin-5-one N(4)-substituted thiosemicarbazones and their copper(II) complexes

\begin{tabular}{|c|c|c|c|c|c|c|}
\hline & \multirow{2}{*}{ Compound } & \multicolumn{5}{|c|}{ Concentration } \\
\hline & & $200^{\mathrm{a}}$ & 400 & 600 & 1000 & 1600 \\
\hline & HBATP4DH & 29840 & 24480 & & & \\
\hline 1 & {$\left[\mathrm{Cu}(\mathrm{HBATP} 4 \mathrm{DH}) \mathrm{Cl}_{2}\right] .2 \mathrm{H}_{2} \mathrm{O}$} & 30110 & 24510 & 21460 & 14460 & \\
\hline 2 & {$\left[\mathrm{Cu}(\mathrm{HBATP} 4 \mathrm{DH}) \mathrm{Br}_{2}\right] \cdot \mathrm{H}_{2} \mathrm{O}$} & 29860 & 24780 & 20480 & 14260 & \\
\hline 3 & {$[\mathrm{Cu}(\mathrm{BATP} 4 \mathrm{DH})(\mathrm{OAc})]_{2} \cdot \mathrm{H}_{2} \mathrm{O}$} & 29840 & 24470 & & 17460 & \\
\hline \multirow[t]{2}{*}{4} & $\left.\left[\mathrm{Cu}(\mathrm{HBATP} 4 \mathrm{DH})_{2}\right] \cdot\left(\mathrm{BF}_{4}\right)_{2}\right]$ & 29780 & 24260 & 18740 & 14940 & $13630(\mathrm{sh})$ \\
\hline & HBATP4M & 29920 & 24070 & 22180 & & \\
\hline 5 & {$\left[\mathrm{Cu}(\mathrm{HBATP} 4 \mathrm{M}) \mathrm{Cl}_{2}\right] . \mathrm{H}_{2} \mathrm{O}$} & 30250 & 23460 & 22150 & 17210 & $16460(\mathrm{sh})$ \\
\hline 6 & {$\left[\mathrm{Cu}(\mathrm{HBATP} 4 \mathrm{M}) \mathrm{Br}_{2}\right]$} & 29960 & 24260 & & 14370 & \\
\hline 7 & {$[\mathrm{Cu}(\mathrm{BATP} 4 \mathrm{M})(\mathrm{OAc})]_{2}$} & 30430 & 23870 & & 17560 & $14690(\mathrm{sh})$ \\
\hline \multirow[t]{2}{*}{8} & $\left.\left[\mathrm{Cu}(\mathrm{HBATP} 4 \mathrm{M})_{2}\right] \cdot\left(\mathrm{BF}_{4}\right)_{2}\right] \cdot \mathrm{H}_{2} \mathrm{O}$ & 29890 & 24710 & & 18270 & $14320(\mathrm{sh})$ \\
\hline & HBATP4DM & 30160 & 28240 & 24610 & & \\
\hline 9 & {$\left[\mathrm{Cu}(\mathrm{HBATP} 4 \mathrm{DM}) \mathrm{Cl}_{2}\right] . \mathrm{H}_{2} \mathrm{O}$} & 29980 & 27870 & 22040 & 15840 & $14040(\mathrm{sh})$ \\
\hline 10 & {$\left[\mathrm{Cu}(\mathrm{HBATP} 4 \mathrm{DM}) \mathrm{Br}_{2}\right] \cdot 2 \mathrm{H}_{2} \mathrm{O}$} & 30280 & 27980 & 23610 & 15880 & \\
\hline 11 & {$[\mathrm{Cu}(\mathrm{BATP} 4 \mathrm{DM})(\mathrm{OAc})]_{2} \cdot \mathrm{H}_{2} \mathrm{O}$} & 29840 & 27880 & 23480 & 17680 & \\
\hline \multirow[t]{2}{*}{12} & {$\left[\mathrm{Cu}(\mathrm{HBATP} 4 \mathrm{DM})_{2}\right] \cdot\left(\mathrm{BF}_{4}\right)_{2}$} & 29780 & 27890 & 22760 & 17360 & $16240(\mathrm{sh})$ \\
\hline & HBATPpip & 31680 & 23840 & & & \\
\hline 13 & {$\left[\mathrm{Cu}\right.$ (HBATPpip) $\left.\mathrm{Cl}_{2}\right]$} & 31780 & 27430 & 24380 & 16480 & \\
\hline 14 & {$\left[\mathrm{Cu}\right.$ (HBATPpip) $\left.\mathrm{Br}_{2}\right] \cdot \mathrm{H}_{2} \mathrm{O}$} & 31670 & 26750 & & 16870 & \\
\hline 15 & {$[\mathrm{Cu}$ (BATPpip) $(\mathrm{OAc})] \cdot \mathrm{H}_{2} \mathrm{O}$} & 30860 & 27260 & 21380 & 17740 & \\
\hline 16 & $\left.[\mathrm{Cu} \text { (HBATPpip })_{2}\right] \cdot\left(\mathrm{BF}_{4}\right)_{2} \mathrm{H}_{2} \mathrm{O}$ & 30540 & 27680 & 20480 & 16470 & \\
\hline
\end{tabular}

sh: shoulder not resolved

Table 4. Solution (DMSO) electronic spectra $\left(\mathrm{cm}^{-1}\right)$ of 4-Benzoyl-3-methyl-1-phenyl-2-pyrazolin-5-one N(4)-substituted thiosemicarbazones and their copper(II) complexes

\begin{tabular}{|c|c|c|c|}
\hline No. & Compound & Intraligand and charge transfer bands & $\mathrm{d} \rightarrow \mathrm{d}$ bands \\
\hline & HBATP4DH & $29780(4.41) 27810$ & \\
\hline 1 & {$\left[\mathrm{Cu}(\mathrm{HBATP} 4 \mathrm{DH}) \mathrm{Cl}_{2}\right] \cdot 2 \mathrm{H}_{2} \mathrm{O}$} & $29810(4.71) 2794021870$ & $14270(2.26)$ \\
\hline 2 & {$\left[\mathrm{Cu}(\mathrm{HBATP} 4 \mathrm{DH}) \mathrm{Br}_{2}\right] \cdot \mathrm{H}_{2} \mathrm{O}$} & $29750(4.78) 27880$ & $14380(2.23)$ \\
\hline 3 & {$[\mathrm{Cu}(\mathrm{BATP} 4 \mathrm{DH})(\mathrm{OAc})]_{2} \cdot \mathrm{H}_{2} \mathrm{O}$} & $29940(4.82) 27910$ & $16450(2.32)$ \\
\hline \multirow[t]{2}{*}{4} & $\left.\left[\mathrm{Cu}(\mathrm{HBATP} 4 \mathrm{DH})_{2}\right] \cdot\left(\mathrm{BF}_{4}\right)_{2}\right]$ & $30120(4.86) 28140$ & $15340(2.24)$ \\
\hline & HBATP4M & $30640(4.48) \quad 27840$ & \\
\hline 5 & {$\left[\mathrm{Cu}(\mathrm{HBATP} 4 \mathrm{M}) \mathrm{Cl}_{2}\right] . \mathrm{H}_{2} \mathrm{O}$} & $30670(4.52) \quad 27910$ & $1470(2.23)$ \\
\hline 6 & {$\left[\mathrm{Cu}(\mathrm{HBATP} 4 \mathrm{M}) \mathrm{Br}_{2}\right]$} & $29980(4.55) \quad 27820$ & $14840(2.28)$ \\
\hline 7 & {$[\mathrm{Cu}(\mathrm{BATP} 4 \mathrm{M})(\mathrm{OAc})]_{2}$} & $30120(4.62) \quad 27860$ & $17310(2.51)$ \\
\hline \multirow[t]{2}{*}{8} & $\left.\left[\mathrm{Cu}(\mathrm{HBATP} 4 \mathrm{M})_{2}\right] \cdot\left(\mathrm{BF}_{4}\right)_{2}\right] \cdot \mathrm{H}_{2} \mathrm{O}$ & $29780(4.69) \quad 27810$ & $15120(2.34)$ \\
\hline & HBATP4DM & $30280(4.39) \quad 24640$ & \\
\hline 9 & {$\left[\mathrm{Cu}(\mathrm{HBATP} 4 \mathrm{DM}) \mathrm{Cl}_{2}\right] \cdot \mathrm{H}_{2} \mathrm{O}$} & $30170(4.42) \quad 26740$ & $15240(2.23)$ \\
\hline 10 & {$\left[\mathrm{Cu}(\mathrm{HBATP} 4 \mathrm{DM}) \mathrm{Br}_{2}\right] \cdot 2 \mathrm{H}_{2} \mathrm{O}$} & $29880(4.45) \quad 27240$ & $15160(2.27)$ \\
\hline 11 & {$[\mathrm{Cu}(\mathrm{BATP} 4 \mathrm{DM})(\mathrm{OAc})]_{2} \cdot \mathrm{H}_{2} \mathrm{O}$} & $29480(4.64) \quad 26480$ & $16780(2.56)$ \\
\hline \multirow[t]{2}{*}{12} & {$\left[\mathrm{Cu}(\mathrm{HBATP} 4 \mathrm{DM})_{2}\right] \cdot\left(\mathrm{BF}_{4}\right)_{2}$} & $30120(4.73) 27020$ & $15470(2.38)$ \\
\hline & HBATPpip & $29580(4.21) \quad 24380$ & \\
\hline 13 & {$\left[\mathrm{Cu}\right.$ (HBATPpip) $\left.\mathrm{Cl}_{2}\right]$} & $28540(4.32) \quad 26480$ & $15940(2.43)$ \\
\hline 14 & {$\left[\mathrm{Cu}\right.$ (HBATPpip) $\left.\mathrm{Br}_{2}\right] \cdot \mathrm{H}_{2} \mathrm{O}$} & $29650(4.38) 27130$ & $15230(2.38)$ \\
\hline 15 & {$[\mathrm{Cu}($ BATPpip $)(\mathrm{OAc})] \cdot \mathrm{H}_{2} \mathrm{O}$} & $29470(4.52) \quad 26540$ & $17790(2.38)$ \\
\hline 16 & $\left.[\mathrm{Cu} \text { (HBATPpip })_{2}\right] \cdot\left(\mathrm{BF}_{4}\right)_{2} \mathrm{H}_{2} \mathrm{O}$ & $30140(4.54) \quad 25890$ & $15690(2.43)$ \\
\hline
\end{tabular}

The solution spectra (DMSO) of the 4-benzoyl-3-methyl-1phenyl-2-pyrazolin-5-one N(4)-substituted thiosemicarbazones and their copper(II) complexes are presents in (Table 4). A peak associated with an $n \rightarrow \pi^{*}$ transition of the heterocyclic ring portion of the pyrazolin moiety is observed at about $35000 \mathrm{~cm}^{-1}$ in the spectra of the thiosemicarbazones and is unshifted in the spectra of their copper(II) complexes. A second band at $c a .3000 \mathrm{~cm}^{-1}$, due to the $\mathrm{n} \rightarrow \pi^{*}$ transition of the azomethine portion of the thiosemicarbazone moiety, has molar absorptivity, $\varepsilon$, of approximately $3 \times 10^{4}$ for the coordinated and uncoordinated ligand. Although a $\mathrm{Cl} \rightarrow \mathrm{Cu}^{\text {II }}$ charge transfer band might also be expected in this region of spectrum. A second $\pi \rightarrow \pi^{*}$ transition associated with the thione portion of the thiosemicarbazone moiety often appears as a low energy shoulder in the range of $23000-28000 \mathrm{~cm}^{-1}$. In the complexes, this band generally merges with the $n \rightarrow \pi^{*}$ transition of the azomethine portion of the thiosemicarbazone moiety and, therefore, bands in this region of the complexes are assignable to $\mathrm{S} \rightarrow \mathrm{Cu}^{\mathrm{II}}$ and other ligand to copper(II) charge transfer bands [31]. The solution $\mathrm{d} \rightarrow \mathrm{d}$ bands are altered from their energies in the solid state, suggesting that significant interaction with DMSO solvent molecules occurs. All 
complexes exhibit a $\mathrm{d} \rightarrow \mathrm{d}$ band as weak shoulders in the visible region whose maximum of absorption lie in the visible region $\sim 16000 \mathrm{~cm}^{-1}$, such a feature is expected for a square planar chromophore in accordance with earlier reports [30, 32]. For the square planar complexes with $d_{x} 2-y^{2}$ ground state, three spin allowed transitions are possible. In order to obtain additional information about the structure of the chelates, their spectra in pyridine were recorded. The presence of only one broad band at $c a .15000 \mathrm{~cm}^{-1}$ implies that the square planar configuration has been changed in a donor solvent, thus indicating that pyridine is coordinated [33].

\subsection{Electronic Spin Resonance Spectral Studies}

The powder ESR parameters of the copper(II) complexes measured at room temperature are shown in (Table 5). The lower $g_{/ /}$values found for the bromo complexes are consistent with the greater covalency of the bromo compared to a chloro ligand as noted before in heteronuclear thiosemicarbazone complexes [34]. The lower the $g_{/ /}$values of the chloro and acetato complexes suggest that the latter are likely four coordinate with acetato oxygen bridging. A lower $g_{/ /}$values of the tetrafluoroborate complexes indicate more covalent planar bonding due to the presence of two sulfur donors; the two ligands are likely bidentate $\mathrm{N}, \mathrm{S}$ donors [35]. The trend $g_{/ /}>g_{\perp}>2.003$ observed for all complexes (for $g$ tensors with orthorhombic splitting we take $g_{\perp}=\left(g_{2}+g_{3}\right) / 2$ indicates that the unpaired electron most likely resides in the $\mathrm{d}_{\mathrm{x}}{ }^{2}-\mathrm{y}^{2}$ orbital. Also, the g-tensor values of $\mathrm{Cu}(\mathrm{II})$ complexes can be used to derive the ground state. In tetragonally elongated octahedron the $3 \mathrm{~d}$ unpaired electron for the $\mathrm{Cu}^{2+}$ ion lies in the $\mathrm{d}_{\mathrm{x}}{ }^{2}-\mathrm{y}^{2}$ orbital [36] $\left({ }^{2} \mathrm{~B}_{1 \mathrm{~g}}\right.$ as the ground state). The $g$ values are then given by $g_{/ /}=2(2-4 \lambda$

$\left./ \Delta_{1}\right)$ and $g_{\perp}=2\left(1-\lambda / \Delta_{2}\right)$. On the other hand, for a tetragonally compressed octahedron, the electron lies in the $\mathrm{d}_{\mathrm{Z}}{ }^{2}$ orbital ( ${ }^{2} \mathrm{~A}_{1}$ ground state ). The $\mathrm{g}$ values are given by $g_{/ /}=2$ and $\mathrm{g}_{\perp}=2\left(1-3 \lambda / \Delta_{3}\right)$. Where $\Delta_{1}, \Delta_{2}$ and $\Delta_{3}$ correspond to $\mathrm{d}_{\mathrm{x}}{ }^{2}-\mathrm{y}^{2} \rightarrow \mathrm{d}_{\mathrm{xy}}, \mathrm{d}_{\mathrm{x}}{ }^{2}-\mathrm{y}^{2} \rightarrow \mathrm{d}_{\mathrm{xz}} \mathrm{d}_{\mathrm{yz}}$ and $\mathrm{d}_{\mathrm{x}}{ }^{2}$ $-\mathrm{y}^{2} \rightarrow \mathrm{d}_{\mathrm{z}}{ }^{2}$ excitations, respectively. From the observed $\mathrm{g}$ values (Table 6) it is clear that the unpaired electron lies predominantly in the $\mathrm{d}_{\mathrm{X}}{ }^{2}-\mathrm{y}^{2}$ and implying $\mathrm{a}{ }^{2} \mathrm{~B}_{1 \mathrm{~g}}$ as a ground state. Kiveslson and Neiman [37] have suggested that the $g_{/ /}$value in the $\mathrm{Cu}(\mathrm{II})$ complex can be used as a measure of covalent character of the metal-ligand bond. For the ionic environment it the $g_{/ /}$value is normally 2.3 or higher and for the covalent environment it is less than 2.3. Using this criterion the data show considerable covalent character of the metal-ligand bond in the present complexes. The ESR parameters $g_{/ /}, g_{\perp}$ and the energies of the $d-d$ transitions for the acetate complexes were used to evaluate the Racah parameters: $k_{/ /}^{2}$ and $k_{\perp}^{2}$, which may be regarded as measures of the covalency of the in-plane $\pi$-bonding and out-of plane $\pi$-bonding, respectively. In these complexes $g_{/ /}>g_{\perp}>2.003$, which is consistent with $\mathrm{d}_{\mathrm{X}}{ }^{2}-\mathrm{y}^{2}$ ground state. Thus, the absorption band in the electronic spectrum at ca. $14000 \mathrm{~cm}^{-1}$ is due to $\Delta_{1}$ and the one at $c a .17000 \mathrm{~cm}^{-1}$ is due to $\Delta_{2}$ with the weaker $\Delta_{3}$ transition between these two values. The following simplified expressions were used to calculate the bonding parameters $k_{/ /}^{2}$ and $k_{\perp}^{2}$ [38].

$$
k_{/ /}^{2}=\left(g_{/ /}-2.0023\right) \Delta_{2} / 8 \lambda_{\circ}, k_{\perp}^{2}=\left(g_{\perp}-2.0023\right) \Delta_{1} / 2 \lambda_{\circ}
$$

Where $\lambda_{\mathrm{o}}$ is the spin-orbit coupling of the free copper(II) ion $\left(\lambda_{0}=-828 \mathrm{~cm}^{-1}\right)$. Hathaway [39] pointed out that for pure sigma bonding, $k_{/ /} \cong k_{\perp} \cong 0.77$ and for in-plane $\pi$ bonding, $k_{/ /}<k_{\perp}$; while for out-of-plane $\pi$-bonding, $k_{/ /}>$ $k_{\perp}$. The acetate complexes under study it is observed that $k_{/ /}<k_{\perp}$ which indicates the presence of significant inplane $\pi$-bonding [40].

Table 5. E.s.r. spectral parameters of the copper(II) complexes of 4-Benzoyl-3-methyl-1-phenyl-2-pyrazolin-5-one N(4)-substituted thiosemicarbazones

\begin{tabular}{|c|c|c|c|c|c|c|c|}
\hline No. & Compound & Phase & Temp. & $g_{/ /}$ & $\mathbf{g}_{2}$ & $\mathbf{g}_{\perp}$ or $\mathbf{g}_{3}$ & $g_{a v}$ or $g_{0}$ \\
\hline 1 & {$\left[\mathrm{Cu}(\mathrm{HBATP} 4 \mathrm{DH}) \mathrm{Cl}_{2}\right] \cdot 2 \mathrm{H}_{2} \mathrm{O}$} & Solid & RT & 2.206 & & 2.049 & 2.101 \\
\hline 2 & {$\left[\mathrm{Cu}(\mathrm{HBATP} 4 \mathrm{DH}) \mathrm{Br}_{2}\right] \cdot \mathrm{H}_{2} \mathrm{O}$} & Solid & RT & 2.186 & & 2.044 & 2.091 \\
\hline 3 & {$[\mathrm{Cu}(\mathrm{BATP} 4 \mathrm{DH})(\mathrm{OAc})]_{2} \cdot \mathrm{H}_{2} \mathrm{O}$} & Solid & RT & 2.188 & & 2.045 & 2.093 \\
\hline 4 & $\left.\left[\mathrm{Cu}(\mathrm{HBATP} 4 \mathrm{DH})_{2}\right] \cdot\left(\mathrm{BF}_{4}\right)_{2}\right]$ & Solid & RT & 2.166 & & 2.036 & 2.079 \\
\hline 5 & {$\left[\mathrm{Cu}(\mathrm{HBATP} 4 \mathrm{M}) \mathrm{Cl}_{2}\right] . \mathrm{H}_{2} \mathrm{O}$} & Solid & RT & 2.213 & & 2.052 & 2.106 \\
\hline 6 & {$\left[\mathrm{Cu}(\mathrm{HBATP} 4 \mathrm{M}) \mathrm{Br}_{2}\right]$} & Solid & RT & 2.189 & & 2.046 & 2.094 \\
\hline 7 & {$[\mathrm{Cu}(\mathrm{BATP} 4 \mathrm{M})(\mathrm{OAc})]_{2}$} & Solid & RT & 2.184 & 2.058 & 2.094 & 2.112 \\
\hline 8 & $\left.\left[\mathrm{Cu}(\mathrm{HBATP} 4 \mathrm{M})_{2}\right] \cdot\left(\mathrm{BF}_{4}\right)_{2}\right] \cdot \mathrm{H}_{2} \mathrm{O}$ & Solid & RT & & & & 2.054 \\
\hline 9 & {$\left[\mathrm{Cu}(\mathrm{HBATP} 4 \mathrm{DM}) \mathrm{Cl}_{2}\right] \cdot \mathrm{H}_{2} \mathrm{O}$} & Solid & RT & 2.174 & 2.046 & 2.035 & 2.085 \\
\hline 10 & {$\left[\mathrm{Cu}(\mathrm{HBATP} 4 \mathrm{DM}) \mathrm{Br}_{2}\right] \cdot 2 \mathrm{H}_{2} \mathrm{O}$} & Solid & RT & 2.153 & 2.052 & 2.027 & 2.077 \\
\hline 11 & {$[\mathrm{Cu}(\mathrm{BATP} 4 \mathrm{DM})(\mathrm{OAc})]_{2} \cdot \mathrm{H}_{2} \mathrm{O}$} & Solid & RT & 2.184 & 2.056 & 2.036 & 2.02 \\
\hline 12 & {$\left[\mathrm{Cu}(\mathrm{HBATP} 4 \mathrm{DM})_{2}\right] \cdot\left(\mathrm{BF}_{4}\right)_{2}$} & Solid & RT & 2.144 & 2.067 & 2.024 & 2.078 \\
\hline 13 & {$\left[\mathrm{Cu}\right.$ (HBATPpip) $\left.\mathrm{Cl}_{2}\right]$} & Solid & RT & 2.184 & 2.058 & 2.033 & 2.092 \\
\hline 14 & {$\left[\mathrm{Cu}\right.$ (HBATPpip) $\left.\mathrm{Br}_{2}\right] \cdot \mathrm{H}_{2} \mathrm{O}$} & Solid & RT & & & & 2.065 \\
\hline 15 & {$[\mathrm{Cu}$ (BATPpip) $(\mathrm{OAc})] \cdot \mathrm{H}_{2} \mathrm{O}$} & Solid & RT & 2.184 & 2.064 & 2.021 & 2.089 \\
\hline 16 & $\left.[\mathrm{Cu} \text { (HBATPpip })_{2}\right] \cdot\left(\mathrm{BF}_{4}\right)_{2} \mathrm{H}_{2} \mathrm{O}$ & Solid & RT & 2.142 & 2.057 & 2.019 & 2.073 \\
\hline
\end{tabular}


Table 6. TGA data for some copper(II) complexes

\begin{tabular}{|c|c|c|c|c|}
\hline No. & Complex & $\begin{array}{l}\text { Temperature } \\
\text { range }^{\circ} \mathrm{C}\end{array}$ & $\begin{array}{l}\text { Weight loss } \\
\text { Found/(Calcd.) }\end{array}$ & Assignment \\
\hline \multirow{4}{*}{1} & \multirow{4}{*}[\mathrm{Cu}(\mathrm{HBATP}4\mathrm{DH})\mathrm{Cl}_{2}]{$\cdot 2 \mathrm{H}_{2} \mathrm{O}$} & $72-128$ & $5.37(5.91)$ & Loss two molecules of hydrated water \\
\hline & & $194-287$ & $13.95(13.58)$ & i) Loss two coordinated chloride ion \\
\hline & & $287-550$ & $63.89(64.66)$ & ii) Decomposed of organic ligand \\
\hline & & $550^{\circ} \mathrm{C}$ & $15.65(15.24)$ & $\mathrm{CuO}$ \\
\hline \multirow{4}{*}{8} & \multirow{4}{*}[\mathrm{Cu}(\mathrm{HBATP}4\mathrm{M})_{2}]{$\cdot\left(\mathrm{BF}_{4}\right)_{2} \cdot \mathrm{H}_{2} \mathrm{O}$} & $69-130$ & $1.52(1.83)$ & Loss one molecule of hydrated water \\
\hline & & $130-322$ & $18.03(17.61)$ & Loss two molecules of $\mathrm{BF}_{4}$ \\
\hline & & $322-594$ & $74.76(74.12)$ & decomposed of organic ligand \\
\hline & & $594-640$ & $11.96(12.13)$ & $\mathrm{CuS}+2 \mathrm{C}$ \\
\hline \multirow{4}{*}{10} & \multirow{4}{*}[\mathrm{Cu}(\mathrm{HBATP}4\mathrm{DM})\mathrm{Br}_{2}]{$.2 \mathrm{H}_{2} \mathrm{O}$} & $78-136$ & $5.19(5.64)$ & Loss two molecules of hydrated water \\
\hline & & $136-295$ & $25.38(25.01)$ & Loss two molecules of coordinated bromide Decomposed of \\
\hline & & $295-586$ & $59.37(59.40)$ & organic ligand \\
\hline & & $586-684$ & $20.84(20.61)$ & $\mathrm{CuS}+3 \mathrm{C}$ \\
\hline \multirow{4}{*}{15} & \multirow{4}{*}{$\mathrm{Cu}$ (BATPpip)(OAc)]. $\mathrm{H}_{2} \mathrm{O}$} & $64-131$ & $3.51(3.22)$ & Loss one molecule of hydrated water \\
\hline & & $131-247$ & $11.69(10.54)$ & Loss of coordinated acetate \\
\hline & & $247-570$ & $74.76(74.90)$ & Decomposed of organic ligand \\
\hline & & $570-623$ & $13.96(14.20)$ & $\mathrm{CuO}$ \\
\hline
\end{tabular}

s.d: start of decomposition

\subsection{Thermal Studies}

Because the infrared spectra and elemental analyses show the presence of water molecules in the chemical structures of some metal complexes. The thermogravimetric analysis TGA was undertaken for the hydrated $\mathrm{Cu}$ (II) complexes and The TGA data and their assignments are summarized in Table (6). In general, the water of hydration can be considered either as crystal or coordinated water. According to Nikolav et al [41], water eliminated below $150{ }^{\circ} \mathrm{C}$ can be considered as crystal water, and that eliminated above $150{ }^{\circ} \mathrm{C}$ may be due to its coordination to the central metal ion. In the present study the water of hydration was eliminated below $150{ }^{\circ} \mathrm{C}$, which suggests that the water of hydration was crystal water. The amount of water found from the weight loss in the thermogram approaches the theoretical value calculated for mono and dihydrates. A survey of the literature reveals that the order of decomposition by pyrolysis of the constituents of solid complexes is: water, anion, ligand and final residue, corresponding to either metal oxide or free metal. In the present study copper(II) complexes follow this order where the first step $\left(70-130^{\circ} \mathrm{C}\right)$ for all complexes represented the dehydration process. The second step $\left(200-460{ }^{\circ} \mathrm{C}\right)$ for all complexes is the elimination of the chloride, bromide, acetate or tetrafluoroborate group. The third step (400 $680{ }^{\circ} \mathrm{C}$ ) is the complete decomposition of the complexes which ended with copper oxide formation.

\subsection{Antifungal Studies}

Table 7. Activity of 4-Benzoyl-3-methyl-1-phenyl-2-pyrazolin-5-one N(4)substituted thiosemicarbazones and their copper(II) chloride and copper(II) bromide complexes against Aspergillus niger

\begin{tabular}{lllllll}
\hline \multirow{2}{*}{ Compound } & \multicolumn{7}{l}{ Concentration } \\
\cline { 2 - 7 } & $\mathbf{2 0 0}^{\mathbf{a}}$ & $\mathbf{4 0 0}$ & $\mathbf{6 0 0}$ & $\mathbf{1 0 0 0}$ & $\mathbf{1 6 0 0}$ \\
\hline \multirow{2}{*}{1} & HBATP4DH & 6.0 & 6.0 & 6.0 & 6.0 & 6.0 \\
2 & {$\left[\mathrm{Cu}(\mathrm{HBATP} 4 \mathrm{DH}) \mathrm{Cl}_{2}\right] .2 \mathrm{H}_{2} \mathrm{O}$} & 6.0 & 6.0 & 6.0 & 6.0 & 6.0 \\
& {$\left[\mathrm{Cu}(\mathrm{HBATP} 4 \mathrm{DH}) \mathrm{Br}_{2}\right] . \mathrm{H}_{2} \mathrm{O}$} & 6.0 & 6.0 & 6.0 & 6.0 & 6.0 \\
& $\mathrm{HBATP} 4 \mathrm{M}$ & 6.0 & 6.0 & 6.0 & 6.0 & 6.0 \\
\hline
\end{tabular}

\begin{tabular}{lllllll}
\hline \multirow{2}{*}{ Compound } & \multicolumn{7}{l}{ Concentration } \\
\cline { 3 - 7 } & & $\mathbf{2 0 0}$ & $\mathbf{4 0 0}$ & $\mathbf{6 0 0}$ & $\mathbf{1 0 0 0}$ & $\mathbf{1 6 0 0}$ \\
\hline 3 & {$\left[\mathrm{Cu}(\mathrm{HBATP} 4 \mathrm{M}) \mathrm{Cl}_{2}\right] . \mathrm{H}_{2} \mathrm{O}$} & 6.0 & 6.0 & 6.0 & 6.0 & 6.0 \\
4 & {$\left[\mathrm{Cu}(\mathrm{HBATP} 4 \mathrm{M}) \mathrm{Br}_{2}\right]$} & 6.0 & 6.0 & 6.0 & 6.0 & 6.0 \\
& $\mathrm{HBATP4DM}$ & 7.9 & 13 & 15.4 & 20.2 & 23.2 \\
5 & {$\left[\mathrm{Cu}(\mathrm{HBATP} 4 \mathrm{DM}) \mathrm{Cl}_{2}\right] . \mathrm{H}_{2} \mathrm{O}$} & 6.0 & 6.0 & 6.0 & 12.5 & 15.5 \\
6 & {$\left[\mathrm{Cu}(\mathrm{HBATP} 4 \mathrm{DM}) \mathrm{Br}_{2}\right] \cdot 2 \mathrm{H}_{2} \mathrm{O}$} & 6.0 & 6.0 & 6.0 & 6.0 & 6.0 \\
& $\mathrm{HBATPpip}$ & 6.0 & 12.4 & 15.6 & 17.4 & 20.5 \\
7 & {$\left[\mathrm{Cu}(\mathrm{HBATPpip}) \mathrm{Cl}_{2}\right]$} & 7.4 & 11.6 & 14.6 & 18.2. & 22.4 \\
8 & {$\left[\mathrm{Cu}(\mathrm{HBATPpip}) \mathrm{Br}_{2}\right] \cdot \mathrm{H}_{2} \mathrm{O}$} & 6.0 & 7.0 & 12.3 & 14.5 & 14.8 \\
\hline
\end{tabular}

a) $\mu / \mathrm{ml}$; and

b) $\mathrm{mm}$ diameter of the growth inhibition zone ( 6.0 - no inhibition).

Table 8. Activity of 4-Benzoyl-3-methyl-1-phenyl-2-pyrazolin-5-one N(4)substituted thiosemicarbazones and their copper(II) chloride and copper(II) bromide complexes against Paecilomyces variotii.

\begin{tabular}{|c|c|c|c|c|c|c|}
\hline & \multirow{2}{*}{ Compound } & \multicolumn{5}{|c|}{ Concentration } \\
\hline & & $200^{\mathrm{a}}$ & 400 & 600 & 1000 & 1600 \\
\hline & HBATP4DH & $6.0^{\mathrm{b}}$ & 6.0 & 6.0 & 6.0 & 6.0 \\
\hline 1 & {$\left[\mathrm{Cu}(\mathrm{HBATP} 4 \mathrm{DH}) \mathrm{Cl}_{2}\right] \cdot 2 \mathrm{H}_{2} \mathrm{O}$} & 6.0 & 6.0 & 6.0 & 6.0 & 6.0 \\
\hline \multirow[t]{2}{*}{2} & {$\left[\mathrm{Cu}(\mathrm{HBATP} 4 \mathrm{DH}) \mathrm{Br}_{2}\right] \cdot \mathrm{H}_{2} \mathrm{O}$} & 6.0 & 6.0 & 6.0 & 6.0 & 6.0 \\
\hline & НВАТР4M & 6.0 & 6.0 & 6.0 & 6.0 & 12.0 \\
\hline 3 & {$\left[\mathrm{Cu}\right.$ (HBATP4M) $\left.\mathrm{Cl}_{2}\right] . \mathrm{H}_{2} \mathrm{O}$} & 6.0 & 6.0 & 6.0 & 6.0 & 6.0 \\
\hline \multirow[t]{2}{*}{4} & {$\left[\mathrm{Cu}(\mathrm{HBATP} 4 \mathrm{M}) \mathrm{Br}_{2}\right]$} & 6.0 & 6.0 & 6.0 & 6.9 & 6.4 \\
\hline & HBATP4DM & 9.4 & 20.2 & 22.7 & 30.3 & 34.6 \\
\hline 5 & {$\left[\mathrm{Cu}(\mathrm{HBATP} 4 \mathrm{DM}) \mathrm{Cl}_{2}\right] . \mathrm{H}_{2} \mathrm{O}$} & 6.0 & 6.8 & 7.4 & 9.8 & 12.7 \\
\hline \multirow[t]{2}{*}{6} & {$\left[\mathrm{Cu}(\mathrm{HBATP} 4 \mathrm{DM}) \mathrm{Br}_{2}\right] \cdot 2 \mathrm{H}_{2} \mathrm{O}$} & 6.0 & 6.0 & 6.5 & 8.2 & 8.6 \\
\hline & HBATPрір & 6.0 & 13.2 & 14.6 & 18.7 & 21.8 \\
\hline 7 & {$\left[\mathrm{Cu}\right.$ (HBATPpip)Cl $\left.{ }_{2}\right]$} & 16.5 & 20.7 & 21.7 & 23.6 & 28.3 \\
\hline 8 & {$\left[\mathrm{Cu}\right.$ (HBATPpip) $\left.\mathrm{Br}_{2}\right] \cdot \mathrm{H}_{2} \mathrm{O}$} & 7.4 & 9.5 & 12.7 & 14.8 & 16.3 \\
\hline
\end{tabular}

a) $\mu / \mathrm{ml}$; and

b) $\mathrm{mm}$ diameter of the growth inhibition zone (6.0 - no inhibition).

Thiosemicarbazones and some of their copper(II) complexes were assayed for their antifungal activity in order to obtain quick information about their potential use for antitumor agents. Two pathogenic human fungi were used for the assay, Paecilomyces variotii and Aspergillus niger. (Tables 7 and 8) lists the results of antifungal tests of thiosemicarbazones and their copper(II) chlorides and bromides complexes, against Aspergillus niger and Paecilomyces variotii. Against Aspergillus niger, neither of 
the HBATP4DH and HBATP4M exhibit any activity until the highest concentration, $1600 \mu \mathrm{g} / \mathrm{ml}$, presumably due to a lack of hydrogen bonding. HBATP4DM shows a considerable amount of activity, comparable to that of nystatin, a commercially available antifungal agent. The copper(II) complex, [Cu(HBATP4DM)Cl $\mathrm{Cl}_{2}$, was inactive at the lowest three concentrations, but possess some activity at the two highest dilutions. The bromo complexes were completely inactive. This is consistent with the previous findings where the complexes of the smaller thiosemicarbazones were relatively inactive. Against Paecilomyces variotii HBATP4DH and HBATP4M were inactive except at the highest concentration tested. The<smiles>[R]C(=S)NN=C(c1ccccc1)C1C(=O)N(c2ccccc2)N=C1C</smiles>

$$
\begin{array}{ll}
\mathrm{R}=\mathrm{NH}_{2} & \text { HBATP4DH } \\
\mathrm{R}=\mathrm{NH}\left(\mathrm{CH}_{3}\right) & \text { HBATP4M } \\
\mathrm{R}=\mathrm{NH}\left(\mathrm{CH}_{3}\right)_{2} & \text { HBATP4DM } \\
\mathrm{R}=\mathrm{N}\left(\mathrm{C}_{2} \mathrm{H}_{5}\right)_{2} & \text { HBATP3pip }
\end{array}
$$

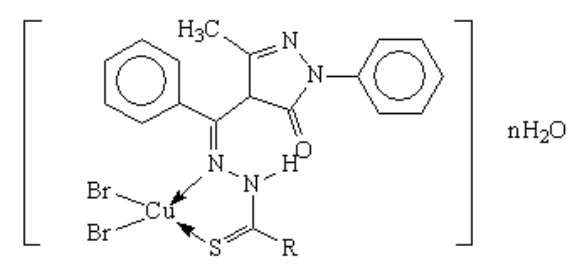
$\begin{array}{ll}\mathrm{R} & \mathrm{n} \\ \mathrm{NH}_{2} & 2 \\ \mathrm{NH}\left(\mathrm{CH}_{3}\right) & - \\ \mathrm{N}\left(\mathrm{CH}_{3}\right)_{2} & 2 \\ \mathrm{~N}\left(\mathrm{C}_{2} \mathrm{H}_{5}\right)_{2} & 1\end{array}$

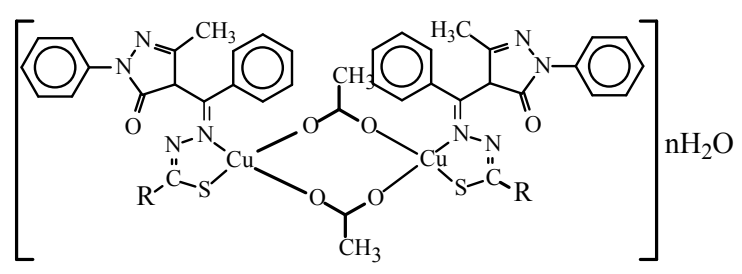
$\mathrm{R}$ $\mathrm{NH}_{2}$ $\mathrm{NH}\left(\mathrm{CH}_{3}\right)$ $\mathrm{NH}\left(\mathrm{CH}_{3}\right)_{2}$ dialkyl thiosemicarbazone, HBATP4DM, showed a tremendous amount of activity at the highest concentration tested $(34.0 \mathrm{~mm}$ of growth inhibition at $1600 \mu \mathrm{g} / \mathrm{ml})$ and was active even at the lowest concentrations tested. Once again, the HBATP4DH and HBATP4M are inactive due to a lack of hydrogen bonded isomers. Copper(II) complexes of HBATP4DM showed a decrease in activity compared to the uncomplexed thiosemicarbazone [42]. This decrease in activity is attributed to either an increase in the size of the compound or a deviation from planarity.

The obtained data are consistent with the proposed chemical structures of the organic ligands and their copper(II) complexes as shown in scheme 1.
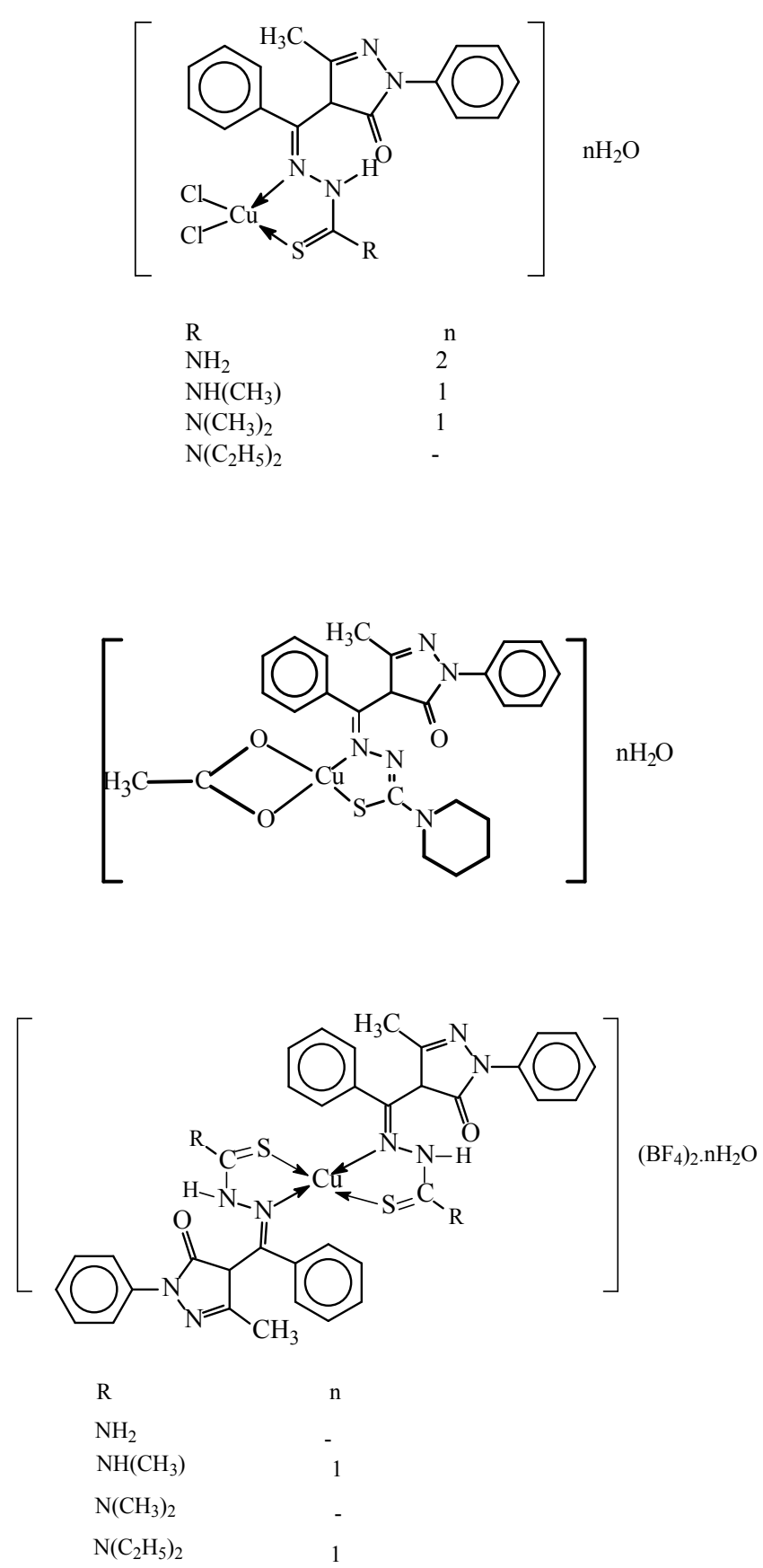


\section{Acknowledgements}

This project was supported by the Deanship of Scientific Research at Salman bin Abdulaziz University under the research project $90 / \mathrm{T} / 33 \mathrm{H}$.

\section{References}

[1] H. Beraldo, D. Gambino, Mini Rev. Med. Chem. 4 (2004) 159-165.

[2] A. Gomez Quiroga, C. Navarro Ranninger, Coord. Chem. Rev. 248 (2004) 119-133.

[3] Angelica E. Graminha, Cl'audia Rodrigues, Alzir A. Batista, Let'icia R. Teixeira, Heloisa Beraldo, Spectrochim. Acta Part A 69 (2008) 1073-1076.

[4] Ming Xue Li, Chun Ling Chen, Dong Zhang, Jing Yang Niu, Bian Sheng Ji, European Journal of Medicinal Chemistry 45 (2010) 3169-3177.

[5] Vukadin M. Leovac, Goran A. Bogdanović, Ljiljana S. Jovanović, Ljubinka Joksović c, ioleta Marković, Milan D. Joksović. Journal of Inorganic Biochemistry 105 (2011) 1413-1421.

[6] Moamen S. Refata, Nashwa M. El-Metwaly, Spectrochimica Acta Part A 92 (2012) 336- 346.

[7] Isolda C. Mendes, Juliana P. Moreira, Antonio S. Mangrich , Solange P. Balena ,Bernardo L. Rodrigues, Heloisa Beraldo, Polyhedron 26 (2007) 3263-3270.

[8] E. Viñuelas-Zahínos, M.A. Maldonado-Rogado, F. Luna-Giles, F.J. Barros-García, Polyhedron 27 (2008) 879-884.

[9] Neelam Bharti,y Shailendra, Sangita Sharma, Fehmida Naqvi, Amir Azam, Bioorganic and Medicinal Chemistry 11 (2003) 2923-2929.

[10] J. Valdes-Martinez, A. Toscano, J. Ramirez-Ortfz, Polyhedron 14 (1995) 579-583.

[11] Yurii A. Simonov, Marina S. Fonari, Janusz Lipkowski, Edward V. Ganinc and Arkadii A. Yavolovskiid, Journal of Supramolecular Chemistry 2 (2002) 415-420.

[12] Ayman K. El-Sawaf, Douglas X. West, Ramadan M. ElBahnasawy, Fathy A. El-Saied, Tansition Met. Chem., 23(1998) 227-232.

[13] Ayman K. El-Sawaf and Douglas X. West, Fathy A. ElSaied and Ramadan M. El- Bahnasawy, Transition Met. Chem., 23(1998) 417-421.

[14] Ayman K. El-Sawaf and Douglas X. West, Fathy A. ElSaied and Ramadan M. El- Bahnasawy, Transition Met. Chem., 22(1997) 360-365.

[15] J. P. Scovill, Phosphorus, Sulfur and Silicon, 60 (1991) 15-19.

[16] A. K. El-Sawaf, D. X. West, F. A. El-Saied and R. M. El-Bahnasawy, Synth. React. Inorg. Met.-Org. Chem., 27(1997)1127.
[17] Abdel-Rahman, L.H., El-Khatib, R.M., Nassr, L.A.E., and Abu-Dief, A. M., J. Mole.Struct., 1040 (2013) 9.

[18] Karen A. Ketcha, Isabel Garcia, John K. Swearingen, Ayman K. El-Sawaf, Elena Bermejo, Alfonso Castin eiras, Douglas X. West, Polyhedron 21 (2002) 859-865.

[19] G. DeVoto, M. Massacesi, R. Pinna and G. Ponticelli, Spectro. chim. Acta, 38A (1982) 725- 731.

[20] Isolda C. Mendes, Marcela A. Soares, Raquel G. dos Santos, Carlos Pinheiro, Heloisa Beraldo, European Journal of Medicinal Chemistry 44 (2009) 1870-1877.

[21] Ayman K. El-Sawaf, Douglas X. West, Fathy A. ElSaied and Ramadan M. El-Bahnasawy, Transition Met. Chem., 23 (1998) 417-421.

[22] Rajeev C. Chikate, Avadhoot R. Belapure, Subhash B. Padhye, Douglas X. West,Polyhedron, 24 (2005) 889899.

[23] K. Nakamoto, Infrared Spectra of Inorganic and Coordination Compounds, Wiley Interscience, NewYork, (1965) p 173.

[24] Ayman K. El-Sawaf, Douglas X. West, Fathy A. ElSaied and Ramadan M. El-Bahnasawy, Transition Met. Chem., 23 (1998) 227-232.

[25] M. Aljahdali, Ahmed A. EL-Sherif, Inorganica Chimica Acta 407 (2013) 58-68.

[26] Dimitra Kovala-Demertzi, Asimina Domopoulou, Mavroudis A. Demertzis, Douglas X.West, Michelle M. Salberg, Gordon A. Bain, Polyhedron, 15(15) 1996 2587-2596.

[27] D.X. West, A.E. Liberta, S.B. Padhye, R.C. Chikate, P.B.Sonawane, A.S. Kumbhar, R.G. Yerande, Coord. Chem. Rev.,123 (1993) 49-54.

[28] M. Joseph, M. Kuriakose, P. Kurup, E. Suresh, A. Kishore, S.G.Bhat, Polyhedron 25 (2006) 61-67.

[29] Douglas X. West, Ayman K. El-Sawaf, Gordon A. Bain, Transition Met. Chem., 23 (1998) 1-6.

[30] I. Babahan, F. Eyduran, E. Poyrazoglu Coban, N. Orhan, D. Kazar, H. Biyik, Spectro. chim. Acta, Part A 121 (2014) 205-215.

[31] P. Sonawane, R. Chikate, A. Kumbhar, S. Padhye and R. J. Doedens, Acta Crystallogr., Sect. C, C47 (1991) 2379 -2385 .

[32] Ayman K. El-Sawaf, Douglas X. West, Fathy A. ElSaied and Ramadan M. El-Bahnasawy, Transition Met. Chem., 22 (1997) 360-365.

[33] A. K. Rana and J. R. Shah, Indian Journal of Chemistry, 21A (1982) 929-931.

[34] D. X. West, H. Gebremedhin, T. J. Romack , A. E. Liberta, Transition Met. Chem., 19 (1994) 426-431.

[35] D. X. West, C. A. Nipp, Transition Met. Chem., 10 (1985) 201-206.

[36] R. C. Agarwal, N. K. Singh, R. P. Singh, Inorg. Chem., 20 (1981) 2794-2798. 
[37] D. Kivelson, R.R. Neiman, J. Chem. Phys. 35 (1961) 149-154.

[38] R.K. Ray, Inorg. Chim. Acta 174 (1990) 257

[39] B.J.Hathaway, Structure and Bonding 14(1973) 60.

[40] U. Sakaguchi, A.W. Addison, J. Chem. Soc., Dalton Trans., (1979) 600 .
[41] E. V. Nikolav, E. Logovin, L. I. Myachina, Thermal Analysis, 2 (1969) 779.

[42] J. Rohith, A. Sreekanth, V. Rajakannan, T.A. Ajith, M.R. Kurup, Polyhedron 23 (2004) 2549-2559. 